\title{
N. C. Ejituwu and the Historiography of Niger Delta Inter-Group Relations
}

\author{
O. C. Asuk (Corresponding author) \\ Department of History \& Diplomatic Studies, University of Port Harcourt \\ Nigeria \\ E-mail: otokpom.asuk@gmail.com
}

Received: February 12, 2020

Accepted: March 15, 2020 Published: June 20, 2020

doi:10.5296/ijch.v7i1.17220

URL: https://doi.org /10.5296/ijch.v7i1.17220

\begin{abstract}
The Niger Delta has an interesting history of inter-group relations with attendant interchange of ideas and influences that reflected its heterogeneous and multi-polar character. However, the apparent predominant historiography of these inter-group relations tend to demonstrate an inherent prejudice against Andoni (Obolo) contrary to historical facts that portray her military exploits and significant influences on the evolution and peopling of the region and beyond. Primarily, this work aims at analyzing the role of Nkparom Claude Ejituwu in the historical reconstruction narratives of the complex inter-group relations woven around inter-marriages, inter-related migrations, commercial rivalries or competitions for economic resources, wars and fluid alliances, and traditional diplomacies with intricate outcomes. The study utilized primary and secondary sources to demonstrate the terrific historical, cultural, economic and political exchanges between Andoni and her neighbours as well as the strength of Ejituwu's scholarship in the deconstruction of orthodox stereotypes in the historiography of Niger Delta inter-group interactions. It concludes that Andoni had developed significant relations with and radically impacted her neighbours before European colonialism altered it to produce critical implications for Andoni in the post-colonial era.
\end{abstract}

Keywords: Ejituwu, Historiography, Niger Delta, Inter-Group Relations, Andoni

\section{Introduction}

Ejituwu's (2004) study is a synthesis of the evolution of Niger Delta historiography covering the pre-colonial, colonial and post-colonial periods. Niger Delta inter-group relations, which evolved several centuries prior to the advent of Europeans, is a major thrust of Nkparom Claude Ejituwu's historiography. The dominant historiography of inter-group relations in the 
Niger Delta, from Dike (1956) to Alagoa (1980), has been coloured by a tendency to underwrite Andoni, and skewed to subdue her under other groups. Dike's work reduced Andoni to a vassal of the Bonny empire. The height of the imperialism of Niger Delta historiography against Andoni is Alagoa"s (1972: p.170) and Cookey's (1974: p.70) untenable positions that King Kpokpo of Nkoro gave Jaja the settlement site of the new city-state of Opobo in the Andoni territory, Alagoa's (1980: p.57) reductionist description of "The Andoni of Opobo areas of the Rivers State", and Lovejoy and Richardson's (2011: p.37) gullible submission that Bonny defeated Andoni around 1700, which Wariboko (2014: p.32) simplistically re-echoed. The deconstruction of this kind of stereotype and orthodoxy in the historiography of Niger Delta inter-group relations was a major concern of Ejituwu's historical narratives (1976; 1989: pp.59-74; 1991; 1992; 2009).

The intermingling of peoples and cultures and attendant exchanges produced varied and complex interrelated outcomes tinted by "symbolic inter-dependence, mutual accommodation and co-operation" in the cultural and economic flanks (Nu-e, 2017: p.1). The relative compactness of the Niger Delta geographical environment extensively encouraged intensive group interactions, movements and exchanges of peoples, goods and ideas due, principally, to the high complementarity of the coastal and hinterland communities (Ajayi and Alagoa, 1980: p.225). The arrival of Europeans totally transformed the character of amicable historical and cultural interactions, and introduced new dimensions and factors into Niger Delta inter-group relations. The transformation culminated in severe political and economic contestations due to conflict of commercial interests that warranted decisive diplomatic overtures like wars and shifting alliances for expansion of territorial frontiers or as counterweight against a budding powerful neighbour in the mercantilist-oriented rivalry of the Atlantic economic struggles for control of resources (Asuk, 2013: pp.146-64). Though all social formations in the Eastern Niger Delta are ancestrally connected in different dimensions (Alagoa, 1972; Ejituwu, 1991), pre-colonial rivalries, alliances and conflicts in the palm oil economy of nineteenth-century Niger Delta constituted the most explosive, impact-oriented and most documented aspect of inter-group relations in the region's historiography.

Ejituwu contributed enormously to the historiography of this intricate web of inter-group relations in the heterogeneous Eastern Niger Delta (Ejituwu, 1976: pp.13-18; 1981; 1989; 1991; 1992; Ejituwu and Okoroafor, 2009; Ejituwu, Jaja and Enemugwem, 2009). He has demonstrated that there are critical historical evidences pointing to new interpretations. His works have also exposed the seemingly scanty and patchy nature of our knowledge of the interactions and exchanges that abound among the communities of the littoral Eastern Niger Delta, as well as between them and their neighbours in the hinterland backdoor. This obvious shortage of knowledge of the diverse historical contacts among the ethnic groups of the Niger Delta have led to the common conclusion that the exchanges have been predominantly characterised by conflict outbursts and devoid of anything harmonious. However, Ejituwu's historiography of Andoni (including her diasporas in Okrika, Kalabari, Ibeno, Oron and Ohafia) relations to her neighbours tend to deconstruct this generalization and demonstrate aspects of inter-group exchanges that tether.

The primary aim of this work is to show the contributions of Ejituwu in the provision of 
critical data and reinterpretation of evidences to demonstrate the gamut of exchanges in the complex inter-group relations among the societies of the Niger Delta. A multi-disciplinary methodological approach is adopted to contribute to the improvement of knowledge of inter-group exchanges in the Niger Delta through the evaluation of the degree of objectivity in the historiography of inter-group relations in the Niger Delta, pursue a reconstruction of the interactions between Obolo (Andoni) and her neighbours, and demonstrate the impact of the complex social phenomenon, especially its mutable and multi-dimensional character, on the region's political and economic development. The work is divided into six sections. The first section is the introduction, which sets its template; the second analyses and identifies the theoretical framework and methodological perspective of the study; the third examines the historical roots of Andoni relations to her neighbours; the fourth briefly discusses the causative factors of the mutational character and nature of inter-group interactions during the period of the Atlantic economy characterized by rivalries, conflicts, alliances and diplomacy; the fifth section pays attention to the impact of inter-group relations on Andoni development; and the last section concludes the work.

\section{Niger Delta Inter-Group Relations: Some Theoretical and Methodological Issues}

Theoretical and methodological considerations, which revolve around the standpoints of arguments and methods of inquiry into any subject-matter, are intimately intertwined because they influence the direction of analysis, selection and arrangement of facts, and the evaluation and interpretation of data (Okpeh, 2006: p.5). This work analytically explores the contending issues in the examination of inter-group relations in the Niger Delta and the direction of dominant literature. The primary feature of any human community is interdependence, which connotes man's relationship to his environment and his fellow man. Onigu Otite (cited in Okpeh, 2006: p.6) shows that the basic need of man is the provision of material goods, which definitely requires co-operating with others in a production and consumption relationship involving struggle for access to the scarce resources. Thus, the complexity and dialectics of existence warrants the conscious or unconscious interaction and interdependence of human groups, which gave rise to the thesis of mutual aid to show that human beings virtually co-operate not just for the sake of social community, but also in the struggle for the basic needs of life (Kropotkin, cited in Okpeh, 2006: p.6).

Furthermore, Kessler (cited in Okolo, 1987: p.183) notes that "... in the evolution of the organic world, in the progressive modification of organic being, mutual support among individuals play a much more important part than their mutual struggle". Scholars of the mutual aid theoretical standpoint acknowledge the preponderance of conflict as a recurrent feature of the complex interaction of human groups in their struggles for scarce resources, but applaud its temporization by consensus and co-operation (Tseror, 1992: pp.12-14). However, in contradistinction to the mutual aid thesis is the theory of natural anarchy of Thomas Hobbes that predominantly influences the realist theory of inter-national relations. To Hobbes, "the natural state of man was that of war in which every man was pitched against every man" (Hobbes, 1958: p.107). The Hobbesian thesis holds that the siege mentality that preponderates society makes survival particularly a traumatic experience. The dominant supposition is that since human groups have differing and competing interests, which 
regularly conflict, harmonious co-habitation and co-operation was hardly a characteristic of human society. The consequence was that life became solitary, poor, nasty, brutish and short (Hobbes, 1958: p.107).

Marxism also sees conflict as dominating human interactions since differing interests that characterize human societies always result in relationships fraught by disagreement, antagonism and conflict. Therefore, the emerging nature of society is disorder not order, and anarchy due to the struggles between groups for means of sustenance and sustainability. In the Marxist materialist conception of history, all human history hitherto has been a history of class struggle; the particular structure of social classes at any given time is determined by the mode of production; the bourgeois order, like all systems, begets contradictions, which cannot be resolved within its framework; the working class will take the initiative of a revolution and acquire a political hegemony; the working class will found a socialist, then a communist society; and, the new culture and science of the socialist or communist societies will constitute a higher achievement than the bourgeois order for the free spirit of man, and will realise the essence of man (Okpeh, 2006).

These standpoints contain inherent weaknesses to warrant a modus vivendi, the integrated theory. Okpeh (2006: p.9) notes that the above theories demonstrate gross inability to explain the variables that make co-operation or conflict the dominant feature of social relations; and perceived society and social relations from a narrow, rigid realm and fixed terms, but ignored their ever-changing nature, form and content. Alternative perspective sees co-operation and conflict as specific and situational instances in the development of human societies, and as historical shifts in the process of change. To close the theoretical lacuna and resolve the inherent explanatory problematic of these analytical models, their revision produce a-bridge-the-gap model that challenges the mono-perceptive and incompatible nature of the theories. The new perspective, the integrated approach, sees the contrasting phenomena of consensus and conflict as inter-changing in the dynamics of the configuring variables in the broad process of inter-group relations. Otite (cited in Okpeh, 2006: p.9) opines that "... consensus and conflict though apparently contrasting and incompatible are co-existing features ... Both consensus and conflict theories may thus apply to different times, or even at the same time, to various socio-territorial units ..."

The understanding of the mutational nature and character of inter-group relations in the region requires scholars to transcend the dichotomy between conflict and consensus as polar opposites that define the connections between human societies, and fix the locus of their interplay in the analysis of groups interaction (Okpeh, 2006: p.10). The political economy of inter-group relations in the Niger Delta can only be properly understood from the adoption of the multi-disciplinary approach. Inter-group relations is perceived as an emergent theme in African historiography that has attracted considerable attention from scholars. Defining inter-group relations from the social psychology perspective, behavioural scientists, Sherif and Sherif (1969: p.88) see them as "states of friendship or hospitality, co-operation or competition, dominance or subordination, alliance or enmity, peace or war between two or more groups and their respective members". Similarly, Andreyeva (1980: p.246) articulates inter-group relations as natural 'interactions' with socio-historical activities collectively acting 
as the mediating factor in the broader system of social conditions.

For the social psychologists, inter-group relations can exist as immediate interactions of representatives of various groups or in extremely mediated impersonal forms. This perspective espouses the stratificational nature of human society in relations to group behavioural pattern, structuralized human relations on the basis of role and status, and wholly concentrated attention on the behaviour of interacting groups, but ignores the fundamental variable, cultural identity, that underpins contact and interactions (Okpeh, 2006: p.11). Beyond this theorization, Afigbo (1987: p.18) holds that inter-group relations are contacts and interactions between different identity groups desirous of making critical inputs into the relationship with some scope and area of autonomous action. Re-echoing Afigbo, Lohor (1998: p.28) asserts that inter-group relations are the symbolical and face-to-face interactions and exchanges between distinct groups and societies. The manifestations of inter-group relations as inter-ethnic, inter-racial, inter-religious, inter-class, inter-generational, inter-national, cross-gender, or inter-supranational reflects human actions. The dominant issue in Afigbo's postulation is identity, which ramifies into variations in natural endowments, comparative and absolute advantages, ethno-cultural peculiarities, and idiosyncrasies of interacting groups. The prevalent assumptions relating to identity issues would be that divergences promote antagonism and conflict due to socio-economic, political and cultural heterogeneity, which represent "indices of differentiation and group atomization" (Okpeh, 2006: p.13).

Yet, Ejituwu's historiography demonstrates that though war emerged in some of the interactions, they were mostly expressed in terms of diplomacy, treaties, commercial and cultural exchanges that produce cultural integration of some sort. Ejituwu (1991) emphasizes the element of mutual reciprocity involving the process of compromise-building as a fundamental imperative in the inter-group relations among Niger Delta polities. Ejituwu's concept of mutual reciprocity in inter-group relations is woven around co-operation that takes the form of trade, diplomatic ties, war and peace, borrowing of aspects of culture for cultural innovations symbolizing it as a multi-faceted and multi-dimensional phenomenon. As Nnoli (1978) observes, it is not contacts between groups that engenders inter-group conflicts, but the degree of competitive political and economic claims among the interacting groups. This is not unconnected with the imperative relative independence of interacting groups, which autonomy is defined in territorial terms and supported by other strategic factors. It is this relative independence and autonomy that provides the structural and institutional frameworks of inter-group interactions (Okpeh, 2006: p.14).

It is against this backdrop that Nwabueze (2003: p.4) sees inter-group relations in a dichotomous lens as "the simple or complex, conflicting or accommodating, co-operating, consensus, peaceful or acrimonious, intense, dense or indifferent way that one group is connected or associated with another in the course of their interaction with each other". They are loaded with "series of methods, strategies or approaches to the understanding of separate group dynamics, of diffusing tension between different groups and creating or building bridges across potential or actual conflict relationships, or directly promoting harmony". Therefore, it signifies a web or network of human experiences across national or cultural 
boundaries which ever-changing nature is complicated by the two contradicting metaphors of co-operation and conflict. Its fundamental dynamism can only be captured when inter-group relations is viewed as a process within a broad continuum delineated into the five stages of: contact and interaction; compromise and co-operation; competition; conflict; and, assimilation and integration (Okpeh, 2006: pp.16-17). Basically, all these stages are inter-connected in their mutual and symbiotic form. However, in a competitive relationship, as shown by Lohor (1998: p.29), different societies or groups struggle independently to derive benefit without necessarily attempting to destroy the other, but seek to marginalize them in order to maintain or achieve their goals with the rewards shared to the detriment of the weaker groups.

This typology was profoundly demonstrated in Ejituwu's $(1989 ; 1991)$ analyses of Andoni-Ibani (Bonny and Opobo) relations from the period of the palm oil trade to colonialism in which the latter adopted unprecedented adroit diplomatic manoeuvres to ensure the transition from an interdependent to a dependent bond against the former. By the dawn of twentieth-century colonialism, the mutational nature of inter-group relations in the Niger Delta has been redefined in accordance to its political economy of exploitation and deconstruction of the unity of colonial subjects. Therefore, the strategic manipulation of ethnic differences and differing cultural backgrounds of the social formations of the Niger Delta became a core ideology of British colonialism. Perhaps, more than any factor, colonialism played havoc to inter-group relations in the Niger Delta by restructuring communal socio-political and economic system as well as patterns of interactions, and critically influenced its historiography. Okpeh (2006: p.20) notes that colonialism completely shattered the organic interdependence among various pre-colonial social formations, was the catalyst of negative changes and continuities in inter-ethnic relations, caused Nigerian groups to lose their relative autonomy which defined their interactions, and eroded the basis for independent action. To add, the exploitative character of colonialism generated a high and intolerable degree of inequality that, in turn, produced destructive socio-economic competition within and between ethnic groups.

Ejituwu (1991) shows that colonialism deliberately subjugated disadvantaged social formations under the advantaged few, and balkanized social formations to under-develop them. The affected social formations, like Andoni persisted under this yoke even till Nigeria's attainment of political independence, and became pathetically marginalized in the post-colonial era. This is so because, as Ekeh (1975: p.93, fn.2) noted, collonialism "form the historical background from which Africa ... advanced to modernity ... determined the peculiar characteristics of modernity ..." Therefore, the type of post-colonial state that the British bequeathed to Nigerians was not capable to undo the contradictions of the colonial political economy. Colonial vestiges were retained in the post-colonial era and contemporary political practices are in large measure products of the colonial experience. Consequently, the nature of post-colonial Nigerian-state contains serious implications for identity formation and inter-group relations from which it cannot insulate itself. Okpeh (2006: p.22) posits that "the post-colonial Nigerian-state lacks autonomy because it is neo-colonial" and, therefore, cannot re-order the disoriented matrix of inter-group relations by the colonial-state. This explains the 
preponderance of intra-and inter-group conflicts and intensified primordial dispositions in the contestations between co-habiting groups for scarce resources in post-colonial Niger Delta.

The neo-colonial state's inability to resolve this historical quandary obfuscates the situation by fragmenting Niger Delta social formations in the name of political restructuring through state and local government creation complemented by the militarization of the region as a means of quenching inter-group tensions. Like Egwu (2001: p.17), Okpeh (2006: p.24) argues that "the use of coercion to create a pseudo-order in a socially volatile and restive environment ... has its roots in our colonial history and got entrenched with the ascendancy of military rule, served to militarized political power in Nigeria". The complication of inter-group relations in the Niger Delta became pronounced in the twilight of the $20^{\text {th }}$ century due to the deepening contradictions of Nigeria's dependent and peripheral capitalist economic system resulting in the economic and political instability in the region, which spilled over into and diminished the capacity of the democratization process to address its complexity (Obi, 2001). The adoption of a meta-theoretical perspective, therefore, is required in the analysis of inter-group relations in the Niger Delta to emphasize the historical, economic, political, social and cultural issues consistent with developments in African historiography.

Methodologically, the scholarship on inter-group relations in the Niger Delta have been grappling with the intractable problem of dearth of relevant sources of data to buttress and sustain critical arguments. Indeed, orthodox historiography of inter-group relations in the Niger Delta has been profoundly influenced by colonial records, much of which was coloured by the brush of imperial exotica underpinned by fundamental prejudices and stereotypes. This problem affected Ejituwu's rigorous attempts to reconstruct the history of Andoni relations with her neighbours in the Niger Delta. Secondly, the challenge of developing appropriate analytical tools to deconstruct certain stereotypes became a critical one. The historical method, "which defines the most essential connections and boundaries of group contacts and interactions on the basis of the passage of time" (Okpeh, 2006:p. 28), can be combined with the political economy approach that emphasizes the extent to which each group has developed its productive forces to objectively analyse inter-group relations; in the Niger Delta. It has also been stressed that inter-group conflicts should be historicized "with the ultimate goal of knowing their roots, the pattern of ... manifestations and implications for the development of the groups involved" Okpeh (2006: p.29). Therefore, the multi-disciplinary methodological approach becomes the appropriate tool for the analysis of the complex social phenomenon of inter-group relations in the Niger Delta, especially its mutable and multi-dimensional character, and impact on regional development.

\section{The Historical Roots of Andoni Relations to Her Neighbours}

Anene (1966: p.7) recorded that the Andoni were the first group to settle in the Eastern Niger Delta, while Alagoa (1972) and Ejituwu (1991) demonstrate that the people has profound historical relationship with all the social formations of the region. Alagoa (1972: pp.163-4) notes also that the Obolo or Andoni (from Ijo, Idoni) were long established in the Eastern Niger Delta and had significant influence on the history of Bonny, featured considerably in the history of the Okrika, while the Kalabari traditions demonstrated that a number of its 
towns had prior settlement in or migrated from Andoni. Andoni did not only provide sanctuary for migrants from numerous Niger Delta social formations, but also sent out migrants to several other places with immense interchange of ideas and influences between them. Corroborating, Opu-Ogulaya of Ogoloma (cited in Ejituwu, 1978: p.28) notes that the Andoni people were the earliest settlers in the Eastern Niger Delta who dominated and controlled the Idontoro River.

Andoni-Kalabari historical relations show that the ancient Akialame and Amabiame wards, and others, of ancient Elem Kalabari, were established by migrants from Old Asarama (Asaramatoru) (Horton, 1998: pp.208-214; Horton, 21/09/2012; Enemugwem, 2006: p. 16-17). Furthermore, the origin of Kalabari national deity, Owameakaso, has been traced to Andoni (Alagoa, 1972; Horton, 1998; Enemugwem, 2006: p.17). However, relating to the founding of (Kala) Ido in the Kalabari territory, Alagoa (1972: p.140) distorted historical facts about their migration from Andoni by attributing it to a flight from the vengeance of the Ibani over the murder of their chief. This position contradicted both Ido and Andoni traditions which recorded their migration from the Andoni community of Unyangala led by Ewelle (Ewile) to escape the terrible activities of Nna Biget, the Andoni equivalent of Bille's Agbaniye Jike (Owukio, cited in Ejituwu, 1991: p.28; Enemugwem, 2006: p.13). Similarly, Alagoa (1972: p.140) shows that "Tombia was founded from the Central Delta town of Ekpetiama and settled first at Nyankpo, then at Okpoma Dapa Tombia in Andoni territory, and later at Iloma Tombia near Finima in the Bonny area" before moving to Kalabari. Nyankpo was a territorial space where Finima and Bonny are presently located. It was part of the original Ayama cycle of the Andoni before the arrival of the Ibani. It was from here the founders of such communities as Kula, Ilotombi, Bille and Tombia moved to their permanent settlements (Ejituwu, 1991: pp.23-4; Boyle 15/6/2011). While not contesting Alagoa's (1972: p.140) reference to Simingi as the national god of Tombia, it is important to note that Simingi was derived from Nyankpo and retained in Andoni, Finima and Tombia till the present day.

With reference to Andoni-Okrika relations, all relevant recorded accounts of the history of Okrika (Porter, 1933; Alagoa, 1972; George, 1981; Ogan, 1988; Ejituwu, 1991; Horton, 1998; Abam, 1999; Enemugwem, 2006) associated Andoni with the origins of Okrika. According to Alagoa (1972: p.145), "... the Koniju founder of Okrika town, Oputibeya, arrived from the Andoni country ..." Afterwards, "... a stranger, Fenibeso by name, a tough looking youngman of about twenty years old, ... a fugitive offender ... migrated to Okopiri (Okochiri) from the area of Ilotombi otherwise known as Idotoru, or Andoni country" (Abam, 1999: p.22; Obuoforibo, 2012: p.5). Fenibeso, who succeeded Oputibeya, took over both political leadership and religious roles, and later "disappeared miraculously into the earth, and was deified thenceforth as the national god of all Okrika" (Alagoa, 1972: p.146; Ejituwu, 1991: p.28; Enemugwem, 2006: p.13). Also, Ogoloma traditions revealed that the people, who were later joined by Isomabou women from the Central Niger Delta, migrated from the Ogoloma village in Andoni due to the oppressive tribute system there (Allison, June 30, 1975; Ejituwu, 1991: p.33; Enemugwem, 2006: p.11).

Traditions from other Okrika communities like Ibaka, Okuru, Ogbogbo, Ogu, Bolo, and Ele demonstrate that they were peopled by migrants from the Andoni area (Ejituwu, 1991: p.28). 
While some Bolo ancestors migrated from the Andoni community of Ilotombi to escape the result of "a curse administered by a woman ...", a group migrated from Fibiri in the Andoni area to settle in Ogbogbo (Oruwari, 1986; Ejituwu, 1991: p.28; Enemugwem, 2006: p.13). Similarly, separate groups of migrants who left their Andoni homeland at Asaramatoru were among the earliest settlers of Ogu and Ele, while the founders of Okuru migrated from Unyangala in Andoni in the 1700s to escape the harsh policies of NnaBiget (Okara, 1984: p.8; Enemugwem, 2006: p.13; Derefaka, 18/02/2012). Nkoro, an Okrika diaspora community that came to settle among the Andoni towards the end of the seventeenth century had a national god, Okwamboku or Okwuanmboko, a war god that is related to Okrika's Fenibeso, derived from Andoni (Alagoa, 1972: pp.167-9; Enemugwem, 2006:p.8). However, in the nineteenth and twentieth century, Andoni-Okrika experienced flashes of conflicts between them (Obuoforibo, 2012; Benson, 2017).

On Andoni-Ibani relations, Dike (1956: p.24), Ejituwu (1991: p.68), and Horton (1998: p.222) demonstrate that the founders of Bonny were attracted to the coast by the prosperity of the seaboard-hinterland trade between the Africans (Andoni) and Portuguese as Andoni slave traders got their supplies from Ndoki, Ibibio and Ogoni. On their arrival, the Ibani settled first at Orupiri on Asaramatoru (Old Asarama) before moving to old Andoni fishing settlements like Okoloama on the Rio Real (Epelle, 1955: pp.9, 39; Alagoa and Fombo, 1972: pp.6, 74; Enemugwem, 2006: p.11). Bishop Crowther (cited in Cookey, 1974: p.15) identifies Andoni villages of Ayambo (Anyamboko), Aganya (Agana), and Iwoma with a population of 300 as having settled close to the site of the CMS mission, now St. Stephen's Anglican Church, prior to the settlement of Bonny. The remnants of the migrations from Old Ilotombi at Nyankpo to Tombia in Kalabari founded Finima, while those from Old Asarama to Abalama founded Abalamabie and Nanabie (Ediyekio, 1984: pp.10-12, 57; Ejituwu, 1991; Enemugwem, 2006: p.11).

The expatriate Ibani groups had extensive interactions with and assimillated the indigenes linguistically and culturally, albeit retained "their names and those of their guardian deities ... as evidence of their original identities" (Horton, 1998: p.222). Intermarriage also played fundamentally critical role in the assimilation and acculturation processes for the retention of the small fraction of the Ibani language against the dominant Ndoki (lbo) language in the post-settlement era. Enemugwem (2006: p.11, citing Tolofari and de Cardi) shows that, on arrival, the Ibani speakers married all Andoni women into their fold and gave out Ibani women to Andoni fishermen as wives to assimilate the indigenous group and increase the population of Ibani speakers. Alagoa and Fombo (1972: p.76) note the importance of post-settlement inter-marriages between the Ibani and Andoni one of which produced King Wari, son of an Andoni mother, who introduced Ikuba as the national god of Bonny from the Ikurube deity of Unyangala (the mother's place). Similarly, Otuburu, the deity of Anyamboko (Andoni) community that relocated from Nyakpo was adopted by the Ibani on their arrival (Enemugwem, 2006: p.9). The "House of Skulls" in Bonny also came from Andoni (Alagoa, 1972: p.154).

The relations between Andoni and the newly established Ibani city-state of Opobo were shaped by the dynamics of the palm oil trade and colonialism. The relations began in 1869 , 
the year of the Bonny civil war, when the fleeing Jaja and his Annie Pepple group, at the instance of M. de Comte Charles de Cardi and Archie Arthur McEachen who were familiar with the Andoni territory, approached its leaders for a possible accommodation (Talbot, 1926: p.208; Alagoa, 1972: p.170; Ejituwu, 1991: pp.135-6; Enemugwem, 2000: p.114). Few years after being granted the opportunity to establish Opobo on the location of Andoni fishing ports or Idoni-Nko-toru on the strategic Otu-Okwan-Nkon, later Opobo River, following the conclusion of crucial traditional taking of a ritual oath of allegiance by Jaja symbolised by the hanging of ritual necklace (igba) round his neck (Alagoa and Fombo, 1972: p.31), the peaceful relations between both groups acknowledged by the Anglo-Opobo Treaty of 1873 collapsed and was replaced by rivalry in the 1880s, which blossomed into full-scale Opobo-Ibeno (Andoni) conflict in 1881 that led to Britain's declaration of the Oil Rivers Protectorate in 1885 and the deportation of Jaja in 1887 (Cookey, 1974: pp.69-70, 92; Ejituwu, 1991: pp.135-57).

The historiography of Andoni relations to her hinterland neighbours of Ndoki, Ibibio and Ogoni recognises the peculiarity of production structures and regional disparities in the distribution of resources, which profoundly influenced the development of internal long-distance exchange relations between them before the advent of Europeans (Dike, 1956; Jones, 1963; Hopkins, 1973; Ejituwu, 1991; Abam, 1999). Andoni migrations into the salt-water environment of the Eastern Niger Delta influenced the development of the fishing occupation and salt-making indigenous industry to a high degree of specialisation, and the exchange of dried fish and salt with the vegetable, food-stuffs and other agricultural products of the hinterland Ogoni, Ndokki and Ibibio in commercial centres located at nodal points on the mainland accessible by water (Ejituwu, 1991: pp.51-2). From the pre-historic period, these hinterland groups have remained very relevant to Andoni's economic sustainability and vice versa with assured continuity and regularity of commercial relations with critical outcomes for the internal cultural, economic and political development dynamics of the region (Nu-e, 2017; Benson, 2017). However, by 1826, the Atlantic economy had offered a mutational character to the Andoni-Ogoni relations when the latter aligned with Bonny against a section of the former (Unyeada). By the last decade of the twentieth century, Andoni-Ogoni relations had witnessed not less than six recorded wars: 1826, 1883, 1921-3, 1927, 1933, 1952-3, 1972-3, and 1993 (Benson, 2017: p.94). Yet, in the contemporary times, Andoni has continued to maintain closer relationship with Ogoni than with any other group in the Eastern Niger Delta in all spheres of human and communal interactions.

\section{Niger Delta Rivalries, Alliances, Wars and Diplomacy in Brief}

This aspect of Niger Delta inter-group relations was a major pre-occupation of Ejituwu's $(1989 ; 1991 ; 1992 ; 2004)$ historiography, which plausibly questions certain orthodoxies with the abiding view to deconstructing subsisting stereotypes with historical evidences and objective interpretations. This deconstructive historiography was a response to the avalanche of lopsided narratives associated with the Atlantic economy alteration of the prehistoric character of inter-group relations and the introduction of the factors of rivalry, alliances, wars and secret diplomatic manoeuvres among Niger Delta social formations of Andoni, Bonny, Nembe-Brass, Elem Kalabari, Okrika, and Opobo particularly in the nineteenth century. In 
the study of these complex relations using the Andoni-Bonny relations as a case study, Ejituwu (1991: pp.112-3) located the critical factors responsible for the exacerbation of rivalries, alliances, wars and diplomacy among Niger Delta social formations in the transition from the slave trade to the trade in agricultural produce or the palm oil economy.

Commercial rivalry was characterized by a competition among Niger Delta trading states to either equal one, excel or dominate another in the pursuit of national commercial interests (Wariboko, 2014). The construction of alliances to increase states' capabilities against perceived mutual security threats covers mutual obligations upon the outbreak of hostilities (Evans and Newnham, 1998: p.15). Alliance formation became a key variable in the balance of power system in a multi-polar nineteenth-century Niger Delta. Entrenched by its heterogeneity, the preponderance of a fluid alliance system was commonplace as the trading states were assumed to balance against a revisionist state's coalition and maintain stability. Dike (1956: p.44) notes that the alliances in the Niger Delta were 'covenants' or solemn leagues cemented with human blood that played the role of treaties. They were dynamic, issue-oriented, and typical of repertoires of state behaviour.

Central to the phenomenon of rivalry and alliance formation is diplomacy, concerned with the management of inter-state relations. Bartson (1996: p.157) submits that trade has traditionally been a concern of diplomacy as trade interests and policies are generally part of the central preoccupations of most states, not the least, Niger Delta city-states. Andre Gunder Frank's (1978: p.214) submission that trade and war were intimately-and reciprocally-related to each other, and to the process of capital accumulation and economic development as a whole critically captures the Niger Delta scenario. While Dike (1956: p.207) notes that war and trade in the Niger Delta alternated with the seasons, Banigo (2008: p.50) observes that trade and violence were twin characteristics in the Niger Delta for over five centuries. In much of mercantilist thinking and practice, there cannot be trade without war or war without trade (Goldin and Reinert, 2007: p.196). However, trade and violence are two contradictory metaphors: one accelerating prosperity, and the other, the culture of poverty. Trade is the thesis, and violence the anti-thesis. Instead of war to increase trade, it decreased trade and attracted the consuls and gunboats to restore it since pacification was a significant pre-requisite of commercial development (Dike, 1956: pp.99-100, 211; Enemugwem, 2000: p.108).

The rivalries included inter-city-states and canoe-houses, and conflicts between African and European merchants (Zeleza, 1993: p.383). Inter-house rivalry (such as between Igbanibo Braide and Amachree, and between Manilla and Annie Pepple) was the perpetual menace to solidarity in the Niger Delta (Anene, 1966: p.10). The rise of a new African merchant class composed primarily of ex-slaves, liberated Africans, and the mission-educated elite marked the beginning of an unprecedented challenge to the commercial and political hegemony of the old ruling class (Dike, 1956: p.117), and the exacerbation of the disintegration of coastal societies. The Bonny civil war of 1869 led to the secession of Jaja and the founding of Opobo in 1870, and the internal political wrangling that rocked Elem Kalabari in 1879 led to the secession of Igbanibo Will-Braid and the founding of Bakana, Abonnema and Buguma, and the disintegration of Elem Kalabari. 
The political uses of trade by the Niger Delta states involved diplomatic initiatives to develop goodwill and gain influence or strategic assets within another state and the hinterland communities. For instance, in 1837, when the news of Alali's (the regent) usurpation of the king's power in Bonny reached the interior markets, hinterland producers loyal to the Royal House of Pepple closed the markets that led to a sharp decline in oil output at the ports (Dike, 1956: p.98). The political uses of trade could even involve coercive sanctions and other forms of punitive behaviour like the Jaja-Odum Egege and Jaja-Ibeno episodes (Cookey, 1974: pp.91-2). Strategic political/diplomatic and cultural exchanges increase trade outputs. Thus, regular exchange of gifts of slaves and ivory between Abokko on the Niger-Benue confluence and the King of Bonny in the 1830s attest to enduring diplomatic ties between them (Kolapo, 1999: pp.111-5). To consolidate commercial relations with their trading partners and in keeping with traditions, New Calabar kings and chiefs would fit out ceremonial gigs in a very expensive and colourful fashion with regular annual presents to the rulers and people of Engenni-Orashi markets for renewal of pledges (Wariboko, 1999: p.160). The existence of 'tariff walls' warranted numerous devices including alliances to enhance the tapping of the resources of other trading states while not competing with them in the smaller markets under their control as in the case of Bille and Bonny on one hand, Bonny and New Calabar over Ndelle on the other.

On the Lower Niger, at the head of the Niger Delta, there were markets open to exploitation by traders from Bonny, Nembe-Brass and New Calabar. Transport differentials were actually in favour of Nembe but they were offset by the higher prices paid for oil on the Rio Real. In Abua and on the Sombreiro River in the Kalabari trading sphere, there were food markets which Bonny had previously freely accessed during the heyday of the slave trade (Jones, 1963: pp.146-7). In early nineteenth-century Niger Delta, there was a seeming free occupational movement and settlement-Okrika men would fish in the Kalabari and Nembe territories, Akassa would pass through Kalabari territory to sell canoes to Bonny. But with the hardening of the oil trade, each state sought to exclude its rivals and allies from buying oil in the markets she claimed her own, attempted to extend its trading empire at the expense of these rivals, and to restrict rivals and their allies from passing through its territory. Inter-state commercial rivalries and wars were profoundly motivated in part by the ancient struggle for political and economic dominance in the Niger Delta (Ejituwu, 1991: p.71). However, the immediate factors responsible for their resurgence and fierceness in the nineteenth century were all causally related to the commercial transition from the slave trade to the produce trading, which necessitated the redefinition of trading monopolies and 'trading empires' by the trading states (Ejituwu, 1991: p.112; Wariboko, 1999: p.153). The crisis that accompanied the fall in oil prices from the 1860s onwards constituted the new and most critical factor responsible for exacerbating the Niger Delta rivalries and conflicts as the pre-1869 struggle for the interior markets were not new developments (Lynn, 1995: pp.57-77).

While the exclusion of a competitor was not very difficult, some of the trading states constructed permanent trading settlements in the hinterland in very close proximity to one another thereby engendering conflict (Jones, 1989: pp.66-7). The inter-connection between these two complex historical processes engendered an unprecedented level of antagonisms 
during the palm oil economy, while the fall in oil prices (1860-91) heightened the already burning situation (Wariboko, 1999: p.154). According to Hopkins (1973: p.48), "a crisis in the foreign trade would intensify internal rivalries by fostering disputes over the allocation of shares in the export trade, over the prices to be asked and given, and over the distribution of reduced profits", thereby cutting into the merchants' profit margins (Zeleza, 1993: p.370). The worsening price regime at the Brass port in 1864 was largely the result of European traders' mutual cooperation to keep prices down. When the Brass merchants resisted, European traders imposed a trade embargo from June to October 1864 to effectively force the Brass traders to submission (Gertzel, 1962: p.362). The devastating economic impact heightened Nembe-Brass desperation to checkmate New Calabar, which led to the Nembe-Brass-New Calabar conflicts of 1864-84 (Wariboko, 1999: p.161). According to Erekosimaet al (1991: p.23), the Orashi was part of what Nembe-Brass claimed as its age-old marketing zone. By the close of Karibo's reign, Kalabari traders were being attacked by Nembe-Brass and their Engenni-Ogbia allies resulting in the war of 1863. Engenni total blockade of the Orashi River at Okarki completely paralysed Kalabari trade in the north-west.

Andoni and Bonny were arch-rivals in the Atlantic economy and their rivalry witnessed one of the most fluid and discreet alliance constructions in Niger Delta inter-group relations (Ejituwu, 1991: p.112). While Jones (1963: p.135) records an Andoni-Kalabari alliance against Bonny, Alagoa and Fombo (1972: p.9) record an Andoni-Kalabari-Okrika alliance against Bonny, Ejituwu (1991: p.69) and Abam (1999: p.178) demonstrate a Bonny-Okrika alliance against Andoni and an Andoni-Okrika alliance against Bonny, Ejituwu (1991: pp.112-6) shows a Bonny-Ogoni alliance against Andoni respectively. This rivalry culminated in protracted wars over the control and dominance of the markets in the Atlantic trade from the seventeenth to nineteenth century (Dike, 1956: p.99; Jones, 1963: p.135; Alagoa and Fombo, 1972: p.11; Ejituwu, 1991: pp.67-9). While Andoni was interested in diverting the trade from Bonny to their side of the Rio Real, Bonny desired uninterrupted access through the Andoni territory into the hinterland (Ejituwu, 1991: p.71). When the slave trade was diverted to Bonny due to the silting up of the Andoni River in the seventeenth century, both of them traded together with the Europeans at Bonny until the 1702-8 war (Enemugwem, 2000: p.108). The Andoni-Bonny war of 1690-97 led to the construction of an Andoni-Kalabari alliance against Bonny and warranted the ascendance of King Perekule to Bonny's monarchy (Jones, 1963: pp.135-6; Alagoa and Fombo, 1972: p.74). While Old Asarama (Asaramatoru), Bonny's closest neighbour and Unyangala fought several wars with Bonny during the slave trade, Unyeada fought with Bonny in the palm oil trade, particularly in 1826 and 1846 (Alagoa and Fombo, 1972: pp.76-7; Ejituwu, 1991: p.71).

The nineteenth-century commercial transition heightened inter-city-states rivalry and the decisive marginalisation of Andoni in the Atlantic economy (Cookey, 1974: p.40; Ejituwu, 1991; Asuk, 2013: pp.146-65). Its struggles for continuous control of access to hinterland markets and retention of a middleman role in the trade conflicted with Bonny interests to break her monopoly for a free passage (Alagoa and Fombo, 1972; Alagoa, 1980: pp.252; Asuk, 1996: p.45). Andoni merchants struggled to utilise the port facilities of Bonny, which has become a clearinghouse and Africa's greatest slave market (Njoku, 2007: p.118). Andoni 
also struggled to send her oil trading canoes through all the hazards of the long stretch of creeks to the Old Calabar port (Eneyo, 1991: p.102). However, Andoni struggles for accommodation in the Atlantic economy were considered as intolerable trade disruptions and acts of subversion by Britain against her economic interest which prompted an Anglo-Bonny alliance and the appearance of a fake "Andoni-Bonny Treaty of 1846" with a clause that reduces Andoni to the status of a Bonny vassal (Ejituwu, 1989: pp.59-74; Eneyo, 1991: p.67). Fortuitously for Andoni, Bonny dominance of the palm oil economy on the African periphery was severely affected by the internal crisis of 1869 that warranted the evacuation of Jaja's Annie Pepple House and the attendant founding of Opobo in 1870 in the Andoni territory.

The adoption of adroit diplomatic manoeuvre in treaty forgery in 1846 by Bonny was aptly referred to as "a diplomatic curiosity" (Baikie, 1856: p.413; Ejituwu, 1989: pp.59-74), a tradition pursued by Europeans either for their economic interest or for their allies (Flint, 1960: p.188, fn.1). According to Alagoa and Fombo (1972: p.75),

...the 'Andoni wars' came to an end with the settlement reached in the treaty claimed by Fombo and Webber to have been concluded by King Opubo in 1826, but dated 1846 in all other sources, and therefore attributable to King William DappaPepple.

The deconstruction of this Anglo-Bonny dubious act against Andoni was a major thrust of Ejituwu's historiography of inter-group relations in the Niger Delta (Ejituwu, 1989: pp.59-74; 1991). It demonstrates the historical prejudice in the documentation of the forged "Andoni-Bonny Treaty of 1846", which did not exist in any British archives, but Bonny (Dike, 1956: p.226), to which Ejituwu $(1981,1989,1991)$ did critical analyses and generated evidences for further re-interpretation. A major dubious factor relating to the Andoni-Bonny Treaty of 1846 is the fact that a traditional oath-taking ritual that ended a war in 1826 could not have metamorphosed into a written document in 1846, two decades after the war. This dubiety affected the authenticity of the document. Moreover, Webber (1931: pp.15-16) shows that this was a war between Bonny and a section of Andoni (Unyeada), and Ejituwu (1991: pp.113-4) confirms that Unyeada went into the war against a Bonny/Southern Ogoni alliance without the consent of Yok-Obolo or the support of the entire Andoni and was defeated. The Bonny sources claimed that the Andoni-Bonny wars ended in 1826 and manipulated the document to cover up the defeat of Bonny by Andoni in 1846, the year Bonny trade recorded a dramatic downturn due to the war of revenge by Andoni (Webber, 1931: p.28; Dike, 1956: pp.98-9; Ejituwu, 1991: pp.112-23). It was this defeat of Bonny that gave Jaja the basis for a negotiation with the leaders of Andoni for a settlement base in their territory in 1869 (Uneh $22 / 04 / 18)$.

Perhaps, the Andoni continually viewed the location of the centre of the oil trade at Bonny as a potential source of further irritation and nursed a silent determination to nail its rival's palm oil trade. The opportunity came in 1869 when Andoni accepted the fleeing Jaja. Bonny had formulated the lie to Consul Livingstone that allowing British trading ships and diversion of trade to Andoni "will be but another road to the oil markets inferior to that of Bonny" (Eneyo, 
1991: pp.105-6). This Andoni silent determination to blockade Bonny access to the hinterland markets and divert British palm oil merchants to her territory was later altered by Jaja's erratic commercial manipulation of the Anglo-Bonny established apathy towards his host as demonstrated in his letter to Lord Granville, which reads:

In my letter to the Consul, I have explained how the treaty of 1846 between Bonny and Andoni if applicable now, applies to me, and not to ManillaPepple House, for it cannot be denied by any one conversant with the facts, that since I was acknowledged King of Opobo in 1873, the Andonis have been looked upon and treated as my subjects (Eneyo, 1991: pp.104-110).

The "Andoni-Bonny Treaty of 1846" is considered "a diplomatic curiosity" due to the uncertain circumstances of its origins to which a critical evaluation has been conducted (Ejituwu, 1989: pp.59-74; 1991: pp.150-4). According to Alagoa and Fombo (1972: p.76),

The treaty itself shows that the Bonny wished to establish their primacy in the area mainly to preserve that situation of free passage for trade ... but also to exclude their rivals of the kingdoms of Okrika and Elem Kalabari.

Oral traditions of Niger Delta city-states acknowledged that Andoni won the 1846 Andoni-Bonny war to which this treaty is referred, but a peace covenant was reached by traditional blood oath-taking for peaceful co-existence and interaction (Ejituwu, 1991: pp.116-7). While Nkoro was never an Andoni village, contrary to Cookey's (1974: p.70) erroneous reference, and its King or representative could not have signed the Treaty as one, the Andoni representatives on the treaty document had no knowledge of its existence and did not participate in any treaty-making parley summoned by any British agents. More so, by 1846, Britain had not become involved in settling inter-group conflicts among Niger Delta trading-states. Britain's involvement only started after the establishment of Consular Rule in 1849 (Jones, 1963: pp.145-55; Wariboko, 1999: p.155). Most importantly, it is plausible to argue that if Andoni was actually a vassal to Bonny, Jaja and the remnants of the Annie Pepple House would not have left Bonny to seek refuge in a vassal state of Andoni to the extent of swearing to an oath of allegiance to Andoni (Cookey, 1974: pp.69-70).

Consuls J. Beecroft, B. Lynslager, and T. J. Hutchinson, as well as European merchants in the palm oil trade, provided the antagonistic groups with weapons of mass destruction (Wariboko, 1999: p.154; Erekosimaet al, 1991: p.22). The end of rivalries and wars was attributed to consular interventions and mediations with the factor of traditional juju swearing played down (Jones, 1963: pp.145-55; Wariboko, 1999: p.155). As significant as consular arbitration was, the most crucial factor in the restoration of relative peace before the inauguration of colonial administration in 1891 under Sir Claude Macdonald remained the reallocation of shares in the foreign trade among the competing states. This reallocation combined with other internal socio-political factors to create a new balance of power with persistent complex conflicts in the Niger Delta (Wariboko, 1999: p.155). 


\section{Impact of Inter-Group Relations on Andoni}

As soon as Jaja established Opobo in the Andoni territory, Opobo replaced Bonny as Andoni's arch-rival and sought to dominate her host. This tendency culminated in Jaja's blockading of the missionaries from penetrating Andoni and Ogoni thereby contributing to their political and economic underdevelopment (Okorosaye-Orubite, 1990:pp.85-6). However, by the third decade of colonialism, the two groups had skilfully and successfully shook-off the political ascendancy of Opobo (Falk, 1933:p.10; Dewhurst, 1938: p.1; Naanen, 2006: p.79). But before then, British Indirect Rule system had suppressed Andoni under her Opobo, Bonny and Ibibio. The entire Andoni was balkanised and organised into four clans with Ngo, Okoroete, and Unyeada and Asarama in the Opobo Division of Calabar Province; and Ataba in the Degema Division of Owerri Province. The Andoni of Ngo clan attended Native Courts at Opobo Town; those of Okoroete clan attended Native Courts at Ukam, Essene and Ibeno; those of Unyeada clan, including Asarama, attended Native Courts at Biori and Kono; and those of Ataba attended Native Court at Bonny in the Degema Division (Ejituwu, 1991: p.167). This process heightened the structures of group differentiation, social disorientation and disarticulation, political subordination, accelerated underdevelopment and national disintegration of Andoni.

Post-colonial Nigerian-state consolidated the colonial fracturing of Andoni by dividing it between Rivers and South-Eastern States in 1967, and Rivers and Akwa Ibom States in 1987, to heighten its vulnerability, and throw it into perpetual obscurity, The inclusion of her western part in the Bonny Local Government Area following the merger with Rivers State in 1976 rather than making it a full-fledge local council area was devastating. The Federal Electoral Commission's (FEDECO) constituency delimitation exercise of 1979 dropped Andoni population from 66,506 in 1963 to 41,064 culminating in the loss of one its seat in the Rivers State House of Assembly in Nigeria's Second Republic (Eneyo, 1988: p.11). It also affected Federal Government's subsequent creation of Local Government Councils as Andoni was denied appropriate recognition and attendant infrastructural development. The intensity of post-colonial marginalisation and underdevelopment of Andoni prompted Ataba's initial rejection of inclusion in the newly created Andoni/Opobo Local Government Area and preference to the Bonny Local Government Area.

Political appointments from Bonny Local Government Area into State Boards, Committees, and Statutory Commissions were skewed in favour of Bonny and Opobo against Andoni: Bonny had twenty-one superior positions, seventeen for Opobo, and four weak ones for Andoni. Moreover, Andoni's thirty-nine primary schools were administered from Opobo with only nine. A science centre was allocated to Opobo with two secondary schools, and another to Bonny with three secondary schools, whereas Andoni with nine secondary schools had none (Asuk, 1996: p.94). Following General Ibrahim Babangida's acceptance of the Ibrahim Dasuki Report on Local Government Reforms, the Fidelis Oyakhilome-led Military Administration in Rivers State (1984-86) appointed councillors from Bonny and Opobo, but none from Andoni with over fifty percent of the total population of Bonny Local Government Area. This scenario of deliberate political manoeuvring against Andoni continued unabated until the creation of a distinct Andoni Local Government Area in 1996. Currently, the politics 
of the crude oil economy skewed against Andoni through a masterly planned act of critical exclusion and marginalisation.

\section{Conclusions}

This work shows that the dominant historiography of inter-group relations in the Niger Delta is fraught with prejudiced stereotypes against disadvantaged groups like Andoni. The plausible conclusion is that Andoni traditions were not collected to verify other traditions for objective historical analyses. Ejituwu's attempts to correct this dominant historiography led to his synthesis of the evolution of Niger Delta historiography in the three time period of pre-colonial, colonial and post-colonial. Though all social formations in the Eastern Niger Delta are ancestrally connected, the arrival of Europeans transformed the character of historical and cultural interactions, and introduced new dimensions and factors that culminated in severe contestations in pursuit of commercial interests and claims over resources that led to wars and shifting alliances. Rivalries, alliances, and colonialism ruptured the historical connections. Ejituwu contributed enormously to the historiography of this intricate web of inter-group relations in the heterogeneous Eastern Niger Delta by collecting historical evidences from various traditions pointing to new interpretations to deconstruct malignant orthodoxies in the historiography of Niger Delta inter-group relations.

Ejituwu has demonstrated that it was with the Ibani (Bonny and Opobo) that Andoni had the most intricate and complex relationships than all her Eastern Niger Delta neighbours and the engaging historiography was profoundly biased and lopsided. He attempts critical scholarship to deconstruct prevailing negative stereotypes of Eastern Niger Delta inter-group relations, and synthesizes interpretations of data relating to the multi-national and multi-lateral interactions in the Eastern Niger Delta from the earliest pre-colonial through the colonial to the post-colonial period. He shows the powerful influence of the dubious 1846 Treaty document which provided the basis for the production of the map of Niger Delta in which Andoni was subsumed under Bonny. The underpinning logic of the 1846 Treaty document was a diplomacy of smart intent by its makers to mislead the British Government representatives and attract support for their lines of action vis-a-vis local political situation and international commercial exchanges. The overall outcome is the critical marginalization of Andoni in the colonial and post- or neo-colonial periods. The present work demonstrated the prime position of Andoni in the historical evolution of the Eastern Niger Delta and the impact of inter-group relations on its development prospects.

\section{References}

Abam, A. S. (1999). The Okrika kingdom: an analysis of the dynamics of historical events. Owerri: Springfield.

Ade-Ajayi, J. F., \&Alagoa, E. J. (1980). Nigeria before 1800: aspects of economic developments and inter-group relations. In Ikime O. (Ed.), Groundwork of Nigerian history (pp. 224-235). Ibadan: Heinemann.

Afigbo, A. E. (1987). The Igbo and their neighbours: inter-Group in south eastern Nigeria to 1953. Ibadan: Ibadan University Press. 


\section{Macrothink

Alagoa, E. J. (1972). A history of the Niger Delta: an historical interpretation of Ijo oral tradition. Ibadan: Ibadan University Press.

Alagoa, E. J. (1980). Peoples of the Cross River Valley and the eastern Niger Delta. In Ikime, O. (Ed.), Groundwork of Nigerian history. Ibadan: Heinemann.

Alagoa, E. J., \&Fombo, A. (1972).A chronicle of Grand Bonny. Ibadan: Ibadan University Press.

Allison, D. (1975). The history of the founding of Ogoloma.Nigerian Tide, June 30. Port Harcourt.

Andreyeva, G. (1980). Social psychology. USSR: Progress Publishers.

Anene, J. C. (1966). Southern Nigeria in transition, 1885-1906: theory and practice in a colonialprotectorate. Cambridge: Cambridge University Press.

Asuk, O. C. (1996). The Problem of Rural Backwardness in Andoni-land: A Historical Explanation. Unpublished B.A. Project, University of Port Harcourt.

Asuk, O. C. (2013). The rise and fall of the Niger Delta: economic and political developments, 1500-2007. Unpublished PhD thesis, University of Port Harcourt, Nigeria.

Baikie, W. B. (1856). Narrative of an exploring voyage. London.

Banigo, Y. (2008). Hostage-taking in the Niger Delta: implications for economic development. In Nwanna-Nzewunwa, O. (Ed.), Niger Delta crisis: yesterday and today (pp. 50-70). Owerri: Springfield Publishers.

Bartson, R. P. (1996).Modern diplomacy. London: Longman.

Benson, R. M. (2017). The Obolo and her neighbours in the eastern Niger Delta, Nigeria, 1800-2000.Unpublished Ph.D Thesis, University of Port Harcourt, Nigeria.

Cookey, S. J. S. (1974). King Jaja of the Niger Delta: his life and times, 1821-1891. New York: Nok Publishers.

Dike, K. O. (1956). Trade and politics in the Niger Delta, 1830-1885: an introduction to economic and political development in Nigeria. Oxford: Clarendon Press.

Ediyekio, M. N. (1984). A history of Abalama.Unpublished B.A. Project, University of Port Harcourt.

Egwu, S. (2001). State and class in Nigeria: context for faming Middle Belt identity. In N. Bagudu, \& D. C. J. Dakas (Eds.), The right to be different: perspectives on minority rights, the cultural Middle Belt and constitutionalism in Nigeria. Jos: League for Human Rights.

Ejituwu, N. C. (1976). Jaja and the Obolo (Andoni).Oduma 3,1, pp.13-18.

Ejituwu, N. C. (1977). The Obolo (Andoni) of the eastern Niger Delta.Unpublished Ph.D Thesis.University of Lagos. 
Ejituwu, N. C. (1978). Obolo (Andoni): c.500-C.1730. Ujama, I, 1, pp.28-37.

Ejituwu, N. C. (1981). The Obolo (Andoni) and Europeans.Ujama, IV, 1, pp.17-33.

Ejituwu, N. C. (1989). The Andoni-Bonny treaty of 1846: a diplomatic curiosity. ODU: Journal of West African Studies, 36, 57-74.

Ejituwu, N. C. (1991).A history of Obolo (Andoni) in the Niger Delta.Oron: Manson Publishers.

Ejituwu, N. C. (1992). Warfare and diplomacy in the Niger Delta. In T. Falola, \& R. Law (Eds.), Warfare and diplomacy in precolonial Nigeria: essays in honour of Robert Smith. Madison.

Ejituwu, N. C. (2004). Thesis, antithesis, synthesis: Niger Delta historiography in time perspective.Inaugural Lecture Series, No.36, University of Port Harcourt, Nigeria.

Ejituwu, N. C., \&Okoroafor, S. I. (2009).The house of skulls: a symbol of warfare \& diplomacy in pre-colonial Niger Delta and Igbo hinterland. Port Harcourt: M and J Grand Orbit.

Ejituwu, N. C., Jaja, J. M., \&Enemugwem, J. H. (2009).The eastern Delta limit. In E. J. Alagoa, T. N. Tamuno, \& J. P. Clark (Eds.), TheIzons of the Niger Delta (pp. 523-547). Port Harcourt: Onyoma.

Ekeh, P. (1975). Colonialism and the two publics in Africa: a theoretical statement. ComparativeStudies in Society and History, 17, 91-112. https://doi.org/10.1017/S0010417500007659

Enemugwem, J. H. (2000). The significance of the Niger Delta to the political and economic development of Nigeria, 1849-1999.Unpublished Ph.d dissertation, University of Port Harcourt.

Enemugwem, J. H. (2006). Obolo and the peopling of the Niger Delta. Monograph Series. Markurdi: Aboki Publishers.

Eneyo, S. (1988).Andoni's classical litigations: the search for social justice. A Paper Delivered at the 20th Annual Convention of the National Union of Andoni Students held at Ibot-Irem, Andoni, 26-29 December.

Eneyo, S. (1991). The Andoni monarchy: an introduction to the history of the kingship institution of the Andoni people. Port Harcourt: Riverside Communications.

Epelle, E. M. T. (1955). The church in the Niger Delta. Port Harcourt: CSS Press.

Erekosima, T. V. et al. (1991). Hundred years of Buguma history and culture. Lagos: Sibon Books Ltd.

Evans, G., \&Newnham, J. (1998).The Penguin dictionary of international relations. London: Pengiun Books. 


\section{Macrothink}

International Journal of Culture and History

ISSN 2332-5518

2020, Vol. 7, No. 1

Flint, J. E. (1960).Sir George Goldie and the making of Nigeria. London: Oxford University Press.

Frank, A. G. (1978).World accumulation, 1492-1789. London: Macmillan. https://doi.org/10.1007/978-1-349-15998-7

George, S. (1981). Okrika reaction to Christianity, 1878-1945.Unpublished B. A. University of Port Harcourt.

Gertzel, C. (1962). Relations between African and European traders in the Niger Delta, 1880-1896.Journal of African History, 3(2), 361-366. https://doi.org/10.1017/S0021853700003261

Goldin, I., \&Reinhert, K. (2007). Globalization for development: trade, finance, aid, migration andpolicy. New York: Palgrave-Macmillan. https://doi.org/10.1596/978-0-8213-6929-6

Hobbes, T. (1958).Leviathan. New York: Maril Co. Ltd.

Hopkins, A. G. (1973).An economic history of West Africa. London: Longman.

Horton, R. (1998). Some fresh thoughts on eastern Ijo origins, expansions and migrations. In N. C. Ejituwu (Ed.), The multi-disciplinary approach to African history: essays in honour of Ebiegberi Joe Alagoa (pp.195-255). Port Harcourt: University of Port Harcourt Press.

Jones, G. I. (1963). The trading states of the Oil Rivers: a study of political development in easternNigeria. London: Oxford University Press.

Jones, G. I. (1989). From slaves to palm oil: slave trade and palm oil trade in the Bight of Biafra. Cambridge African Monograph series, no. 13.

Lohor, S. A. (1998). The Chadic polities of Jos Plateau and their neighbours: a study on inter-group relations among Jos Plateau societies to 1960. An M.Phil/Ph.D Seminar Presented in the Department of History, University of Jos, September 23.

Lovejoy, P. E., \& Richardson, D. (2011). The slave trade ports in the Bight of Biafra in the eighteenth century. In C. A. Brown, \& P. E. Lovejoy (Eds.), Repercussions of the Atlantic slave trade: the interior of the Bight of Biafra and the African Diaspora. Trenton, NJ: Africa World Press.

Lynn, M. (1995). The West African palm oil trade in the nineteenth century and the 'crisis of adaptation'. In R. Law (Ed.), From slavery to legitimate commerce: the commercialtransition in nineteenth century West Africa (pp. 57-77). Cambridge: Cambridge University Press. https://doi.org/10.1017/CBO9780511523861.003

Naanen, B. (2006). You are demanding tax from the dead: the introduction of direct taxation and its aftermath in south-eastern Nigeria, 1928-39. African Economic History, 34, 69-102. https://doi.org/10.2307/25427027

Njoku, R. (2007). Igbo slaves and the transformation of the Niger Delta. In C. J. Korieh, \& F. 
J. Kolapo (Eds.), The aftermath of slavery: transitions and transformations insoutheastern Nigeria (pp. 115-135). Trenton: Africa World Press.

Nnoli, O. (1978).Ethnic politics in Nigeria. Enugu: Fourth Dimension.

Nu-e, U. S. (2017). Ogoni and her neighbours during the colonial period, 1900-1960.Unpublished Ph.D Thesis, University of Port Harcourt, Nigeria.

Nwabueze, N. (2003). Towards a wider understanding of inter-group relations. In R. T. Akinyele (Ed.), Race, ethnicity and nation-building: studies in inter-group relations. Lagos: Rex Charles.

Obuoforibo, B. A. (2012). Groundwork of Okrika history. Port Harcourt: SAMAG Ltd.

Ogan, C. (1988). Unity of a people: search for peace in Okrika, Rivers State, Nigeria. Port Harcourt: The Author.

Okara, S. A. (1984). The history of Ogu Town: from the time of settlement to the present day. Unpublished B.A. Project, University of Port Harcourt.

Okolo, A. (1987). Foreign capital in Nigeria: the roots of underdevelopment. London: Heartland.

Okorosaye-Orubite, A. K. (1990). Factors responsible for educational underdevelopment in Rivers State: a historical perspective. Unpublished Ph.d Thesis, University of Port Harcourt.

Okpeh, O. O. (2006). Conceptual and theoretical issues arising from studies in inter-group relations in Nigeria in the 20th Century. In O. Akinwunmi, O. O., Jr. Okpeh, \& D. J. Gwamna (Eds.), Inter-group relations in Nigeria during the 19 th and 20th centuries (pp. 5-37).Markurdi: Aboki.

Oruwari, D. (1986). A history of Bolo: from earliest times to present. Unpublished B.A Project, University of Port Harcourt, Nigeria.

Porter, J. C. (1933). Intelligence report on the Okrika clan in Degema Division, Owerri Province. NA/I, CSO 26, 29004 DEGDIST 7/5/7.

Sherif, M., \&Sherif, C. W. (1969).Social psychology. Oklahoma: University of Oklahoma Press.

Talbot, P. A. (1926). Peoples of southern Nigeria (Vol. 1). London: Frank Cass.

Tseror, T. (1992).Tiv and their neighbours. Jos: PHLA Press.

Wariboko, W. (1999). New Calabar: the transition from slaves- to produce-trading and the political problems in the eastern Delta, 1848-1891. In R. Law, \& S. Strickrodt (Eds.), Ports of the slave trade (Bights of Benin and Biafra) (pp.153-168). Sterling: Centre of Commonwealth Studies.

Wariboko, W. E. (2014). Elem Kalabari of the Niger Delta: the transition from slave to produce trading under British imperialism. Trenton, NJ: Africa World Press. 


\section{Macrothink}

International Journal of Culture and History

ISSN 2332-5518 2020, Vol. 7, No. 1

Webber, H. (1931).Intelligence report on the Bonny Tribe.NA/I CSO 26, 27226. https://doi.org/10.1080/0034408310260305

Zeleza, P. T. (1993). A modern economic history of Africa, vol. 1: the nineteenth century. Dakar: CODESRIA Books.

\section{Copyright Disclaimer}

Copyright reserved by the author(s).

This article is an open-access article distributed under the terms and conditions of the CreativeCommons Attribution license (http://creativecommons.org/licenses/by/3.0/). 